\title{
Effect of abscisic acid on differentiation and ribulose diphosphate carboxylase of chloroplasts
}

\author{
Sonia Maillard-Sevhonkian and Paul-Emile Pilet \\ Institute of Plant Biology and Physiology of the University \\ 1005 Lausanne, Pl. de la Riponne, Switzerland
}

\begin{abstract}
Daucus carota tissues were grown on Murashige-Skoog medium (MS) at different concentrations with abscisic acid (ABA). Seven bands of chloroplast fractions were obtained on a sucrose gradient. At $10^{-5} \mathrm{M}, \mathrm{ABA}$ highly increased chlorophyll and protein nitrogen content of medium density chloroplasts. With increasing age of the tissues, the most active chloroplasts according to their ${ }^{14} \mathrm{CO}_{2}$ fixation were found in smaller numbers. When treated with $10^{-5} \mathrm{M} \mathrm{ABA}, 34$ day-old tissues cultivated in vitro showed the chloroplast pattern of 110 day-old tissues. The effect of ABA-given to the tissues during a short pretreatment or continuously present in the culture medium-on the ribulose diphosphate carboxylase activity was analysed. It was found that $\mathrm{ABA}$ at $10^{-5}$ M strongly inhibited ${ }^{14} \mathrm{CO}_{2}$ fixation.

Key words: ABA - Chloroplasts - Differentiation enzyme - RuDP-carboxylase -
\end{abstract} Tissue culture.

Analyses of the ABA effects on several tissues cultivated in vitro have given rise to a number of publications (12). In our Institute the changes in the ultrastructure--induced by ABA--have been most particularly studied in the tissues of Rubus hispidus cultivated in vitro $(11,13)$ especially in relation to their growth. Some changes in plastid structures when these tissues were exposed to light for several days have been briefly reported. That is why experiments, using carrot tissues (rich in chloroplasts), were conducted to test the direct action of ABA on the chloroplasts and their chlorophyll content.

\section{Materials and methods}

\section{Materials}

Daucus carota tissue cultures $(4,8-10)$ were maintained on Murashige-Skoog (MS) medium containing $1.7 \times 10^{-6} \mathrm{M}$ IAA and $6 \times 10^{-9} \mathrm{M}$ kinetin. Experiments using different concentrations of abscisic acid ( $\mathrm{ABA}$ ) were conducted with 34 day-old cultures of tissues cultivated in vitro. The activity of ribulose diphosphate ( $R \mathbf{u}-$ DP) carboxylase was analysed using isolated chloroplasts from 48 day-old cultures with or without $\mathrm{ABA}\left(10^{-5} \mathrm{M}\right)$. Similar analyses were done on isolated chloroplasts from 110 day-old cultures pretreated with or without $\mathrm{ABA}\left(10^{-5} \mathrm{M}\right)$.

Methods

Each step of the extraction and isolation of chloroplasts until the osmotic shock 
was checked, on an untreated sample, by electron microscopy (Dr. R. M. Hofer, in a further paper). After this check showed that the technique used yielded mainly structurally intact chloroplasts, as routine electron microscopy examination of every chloroplast preparation would be extremely time-consuming, we checked the pellet placed on a discontinuous sucrose gradient under light microscope and phase contrast. Chloroplasts in this pellet were of several sizes, smaller than those of higher plants, and predominantly of either class I or class II as described by Spencer and Unt (16), and Spencer and Wildman (15). Some of them appeared opaque, the grana difficult to differentiate, the margin of the chloroplasts well defined as described by Leech (6) and Bourdu et al. (2) for membrane-bound chloroplasts; others appeared with a very granular appearance, diffused boundaries, presumably chloroplasts in which the external membrane was not complete, not refractive.

Extraction: Tissues were ground with a mortar and pestle in a semi-frozen extraction buffer $\left(0.02 \mathrm{M}\right.$ glycyl-glycine $+5 \mathrm{mM} \mathrm{MgCl}_{2} \cdot 6 \mathrm{H}_{2} \mathrm{O}+1 \mathrm{~mm}$ mercaptoethanol $+0.33 \mathrm{~m}$ saccharose) (5), and filtered through 4 layers of muslin and 2 layers of nylon gauze (pore size: $50 \mu \mathrm{m}$ ) to remove cellular debris. The muslin was pressed and the filtrate collected and centrifuged $(12,500 \times \mathrm{g}, 2 \mathrm{~min})$. The pellet, corresponding to nearly all the chloroplasts, after light microscope examination, was placed on a discontinuous sucrose gradient $(33-42-51-57-60-63-66-70 \% \mathrm{w} / \mathrm{w})$ and centrifuged $\left(23,000 \times \mathrm{g}, 90 \mathrm{~min}, 5^{\circ} \mathrm{C}\right)$ using the ultracentrifuge Christ Omega 2.

Isolation of chloroplasts: Different types of chloroplasts were separated according to their density. The fractions were successively collected and their index of refraction at $25^{\circ} \mathrm{C}$ measured by refractometry. These fractions were diluted three times with the extraction buffer, without sucrose, and centrifuged ( $2 \mathrm{~min}, 7000 \times \mathrm{g}$ ). The pellets-containing isolated chloroplasts-were taken up in the extraction buffer without sucrose in order to burst (osmotically) the chloroplasts, as Ru-DP carboxylase is found inside the chloroplast $(14,17)$, and to allow substrates to react with active enzyme sites (2).

Ru-DP carboxylase activity: $0.3 \mathrm{ml}$ of the above fractions were mixed with $10 \mu \mathrm{Ci} \mathrm{NaH}^{14} \mathrm{CO}_{3}(50 \mu \mathrm{l}), 0.5 \mu$ mole Ru-DP (disodium salt), $0.4 \mathrm{ml}$ incubation buffer $\left(0.25 \mathrm{~mm}\right.$ glycyl-glycine, $2.5 \mathrm{~mm} \mathrm{MgCl} \cdot 6 \mathrm{H}_{2} \mathrm{O}, 75 \mathrm{~mm} \mathrm{NaHCO}$, mercaptoethanol $5 \mu \mathrm{l} / 250 \mathrm{ml} ; \mathrm{pH} \mathrm{7.8)}(5)$ in scintillation vials, which were then incubated $\left(1 \mathrm{hr}, 25^{\circ} \mathrm{C}\right.$ ) in white light (Philips: TL $40 \mathrm{w} / 33$; blanc super; $1.5 \times 10^{3} \mathrm{lux}$ ).

The reaction was stopped by adding $0.2 \mathrm{ml}$ of $6 \mathrm{~N}$ acetic acid. The vials were then flushed for $4 \mathrm{hr}$ with air to remove the mineral-labelled $\mathrm{CO}_{2}$ in excess, and the samples dried. Then $2.5 \mathrm{ml}$ of $\mathrm{H}_{2} \mathrm{O}$ and $10 \mathrm{ml}$ of Bray's scintillation fluid were added to the dry residues and the radioactivity of each sample was measured in a liquid scintillation counter.

Analytical methods: Chlorophyll content was estimated according to a method previously described $(1,3)$. An aliquot of the aqueous extract was diluted with acetone to adjust the water content to $20 \%(\mathrm{v} / \mathrm{v})$. The absorbance was measured with a recording spectrophotometer at 663,645 and $652 \mathrm{~nm}$.

Protein nitrogen content was estimated according to the Kjeldahl method. To $1 \mathrm{ml}$ of each fraction, $5 \mathrm{ml}$ of $10 \%$ TCA were added. Proteins were precipitated at $4^{\circ} \mathrm{C}$ for $18 \mathrm{hr}$ and the tubes were then centrifuged $(4,200 \times \mathrm{g}, 30 \mathrm{~min})$. The supernatant containing the non-protein nitrogen was discarded. To the pellets were added respectively $1 \mathrm{ml}$ concentrated $\mathrm{H}_{2} \mathrm{SO}_{4}$, a small amount of selenium containing 
catalyst and a few glass beads. The pellets were then hydrolyzed for $18 \mathrm{hr}$ at $330^{\circ} \mathrm{C}$ in a thermobloc (Lievisch, Planta Jenny). Ammonia was distilled according to the Parnas-Wagner method and collected in $0.05 \mathrm{~N} \mathrm{H}_{2} \mathrm{SO}_{4}$. The protein nitrogen was determined by a back titration of the $\mathrm{H}_{2} \mathrm{SO}_{4}$ with $0.02 \mathrm{~N} \mathrm{NaOH}$.

\section{Results and discussion}

First, experiments were performed in order to study changes in the chloroplast distribution with the increasing age of the tissues.

Seven bands were observed in the sucrose gradient (Fig. 1A); they can be classified into three groups, according to their density $\rho$ :

-Group I : light chloroplasts, density 1.141-1.213 (zones 33 to $42 \%$ sucrose)

-Group II : medium chloroplasts, density $1.257-1.280$ (zones 51 to $57 \%$ sucrose)

-Group III : heavy chloroplasts, density 1.304-1.322 (zones 60 and 63 to $66 \%$ sucrose).

In young tissues ( 27 days), there were more light chloroplasts (group I). Those of group II were almost nonexistent, while those of group III were of few importance.

When the tissues became older (48 days), the number of chloroplasts in groups I and III increased. When the tissues were old (110 days), chloroplasts from groups I and III were at about the same level as in the 48 day-old tissues; in contrast, chloroplasts of group II became very abundant. There were a great many middle and high density chloroplasts.

The distribution patterns of chloroplasts, obtained from tissues treated with $A B A$, were changed in the following way (Fig. 1B):

-with $10^{-6} \mathrm{M}$ ABA, the chlorophyll (Fig. 2) and protein (Fig. 3) content of group I

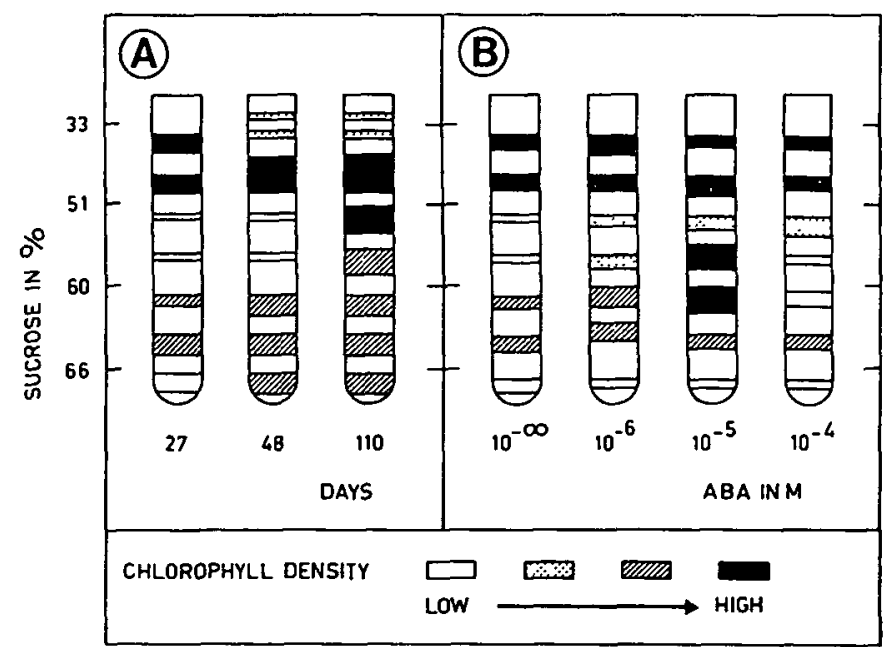

Fig. 1. Changes in chloroplast distribution patterns (separation in sucrose gradient). (A) With increasing age of the tissues (in days) cultivated in vitro. (B) Effect of ABA (at several concentrations). Age of cultures: 34 days. 


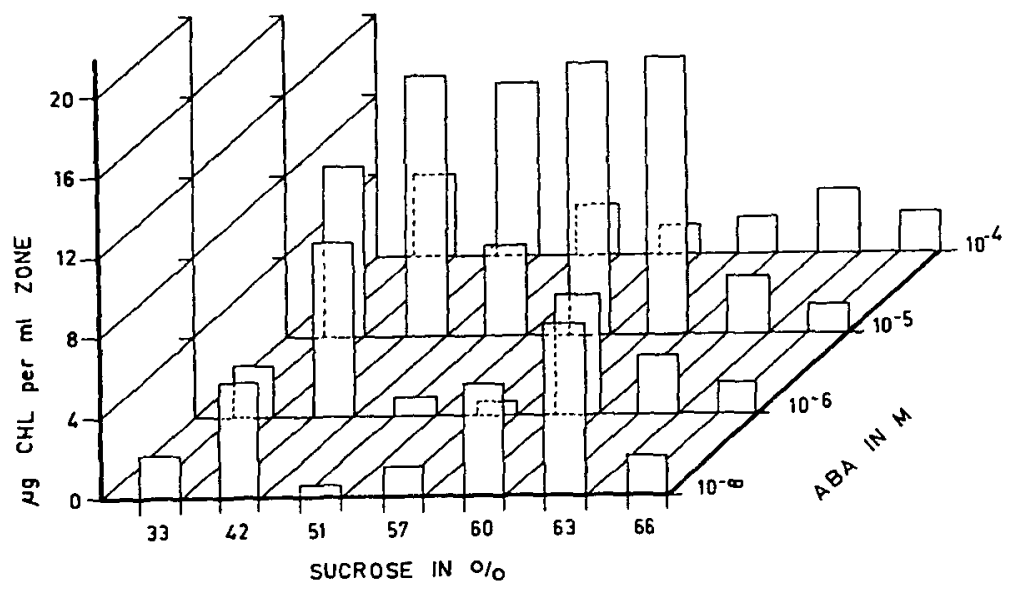

Fig. 2. Chlorophyll content (in $\mu \mathrm{g} \mathrm{ml} \mathrm{zone)} \mathrm{of} \mathrm{the} \mathrm{seven} \mathrm{isolated} \mathrm{chloroplast} \mathrm{sucrose} \mathrm{zones.} \mathrm{Chloroplasts} \mathrm{were}$ prepared from carrot tissues cultivated on Murashige and Skoog medium in the presence of ABA at several concentrations. Age of cultures: 34 days.

chloroplasts increased and became higher than that of group III. Group II chloroplasts were still very few.

$-10^{-5} \mathrm{M}$ ABA, the chlorophyll and protein levels of group I and group II chloroplasts was clearly enhanced. As can be seen in Fig. 2, chlorophyll concentration (in $\mu \mathrm{g} / \mathrm{ml}$ ) rose from 5.81 to 13.00 in the $42 \%$ zone. In the $57 \%$ zone (a very thin band almost undistinguishable in the control), the chlorophyll content rose from 1.44 to $13.49 \mu \mathrm{g} / \mathrm{ml}$. The $51 \%$ zone was stimulated as well as the $60 \%$

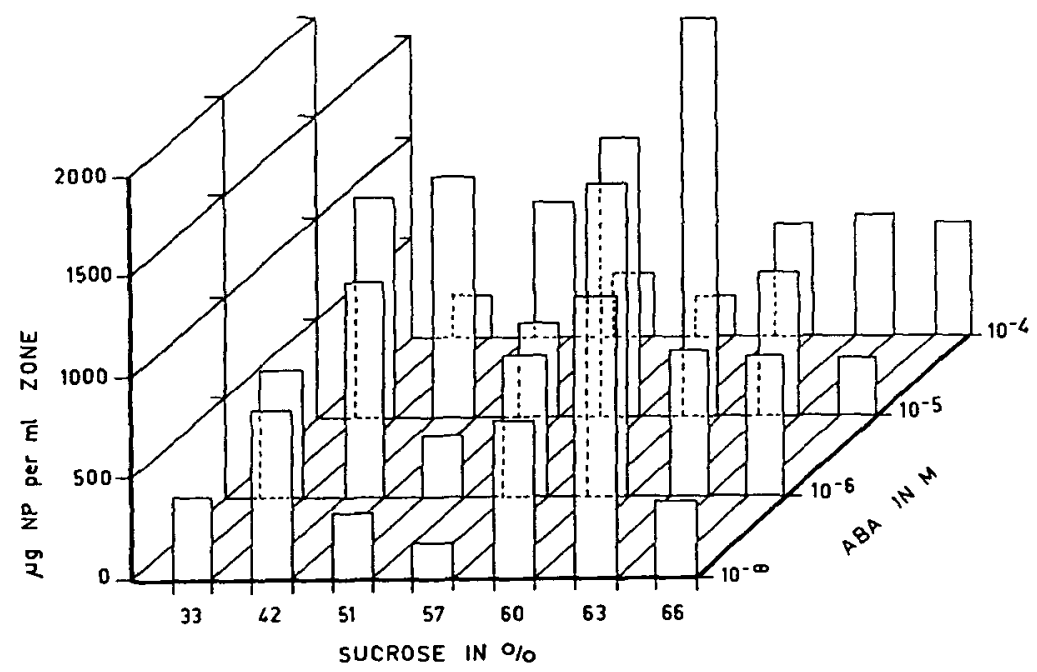

Fig. 3. Protein content (in $\mu \mathrm{g} \mathrm{ml}$ zone) of the seven isolated chloroplast sucrose zones. Chloroplasts were prepared from carrot tissues cultivated on Murashige and Skoog medium in the presence of ABA at several concentrations. See Fig. 2. 
one, in which chlorophyll content was increased from $5.78 \mu \mathrm{g} / \mathrm{ml}$ to $13.78 \mu \mathrm{g} / \mathrm{ml}$. In contrast the $63 \%$ and $66 \%$ zones "degenerated". The protein content (Fig. 3) was found to change in a similar way.

-with $10^{-4} \mathrm{M}$ ABA, stimulation of the light chloroplasts of group I was reduced, compared to the effect of $10^{-5} \mathrm{M}$ ABA while group III zones-60, 63 and $66 \%$ sucrose-were destroyed. The chlorophyll (Fig. 2) and protein (Fig. 3) content for these zones was found to be decreased. Such results were expected, since tissues showed necrosis in the presence of $\mathrm{ABA}$ at a concentration of $10^{-4} \mathrm{M}$.

Next, changes in the chloroplast Ru-DP carboxylases were tested (Tables 1 and 2). As more significant results were obtained with $10^{-5} \mathrm{M} A B A$, a large number of tissue explants were cultivated (fresh weight $=300 \mathrm{~g}$ ) in Erlenmeyer flasks normal MS medium with or without $\mathrm{ABA}$ at $10^{-5} \mathrm{M}$. The Results are reported in Table l, as nanomoles of $\mathrm{CO}_{2}$ incorporated per $\mathrm{mg}$ of Chl, per $\mathrm{ml}$ and per hr, versus sucrose density. As can be seen, $A B A$ has an inhibitory effect on all the zones except on the high density group of chloroplasts.

Such an inhibition of Ru-DP carboxylase activity by ABA was also obtained for the 110 day-old tissues, pretreated $17 \mathrm{hr}$ in a phosphate buffer $\mathrm{pH} 6.1$ (Table 2) containing $10^{-5} \mathrm{M}$ ABA.

When comparing Ru-DP carboxylase activity of untreated 48 day-old and 110 day-old tissues, it may be noticed that $\mathrm{CO}_{2}$ fixation characterised mainly the chloroplasts of $33,42,51,57 \%$ zones. As a matter of fact, in old tissues, the larger number of heavy chloroplasts $\left(57,60,63\right.$ and $66 \%$ sucrose), less active in $\mathrm{CO}_{2}$ fixation, leads the tissues towards necrosis.

Table $\mathrm{I} \quad \mathrm{CO}_{2}$ incorporated in organic compounds expressed in nм for two parameters (per $m g$ of $C H L$ and per $m g$ of NP) in zones of isolated chloroplasts from carrot tissues (cultivated 48 days on the Murashige and Skoog medium, with or without $1 \cdot 10^{-5} \mathrm{M} A B A$ )

\begin{tabular}{ccccccccc}
\hline & \multicolumn{7}{c}{ Concentration of sucrose in \% } \\
\cline { 2 - 9 } & 33 & 42 & 51 & 57 & 60 & 63 & 66 \\
\hline $\begin{array}{c}\text { Average index of } \\
\text { refraction }\end{array}$ & 1.3865 & 1.4139 & 1.4310 & 1.4390 & 1.4471 & 1.4526 & 1.4559 \\
\pm & 0.0030 & 0.0047 & 0.0028 & 0.0014 & 0.0041 & 0.0036 & 0.0017 \\
Density $\mathrm{D}_{4}^{20}(\rho)$ & 1.141 & 1.213 & 1.257 & 1.280 & 1.304 & 1.316 & 1.322 \\
No ABA & $\mathrm{a}$ & 35.5 & 92.0 & 4.6 & 2.8 & 28.6 & 14.2 & 16.5 \\
& $\mathrm{~b}$ & 1890 & 4060 & 507 & 599 & 1710 & 1290 & 1290 \\
& $\mathrm{CO}_{2}(1)$ & 716 & 815 & 821 & 626 & 243 & 301 & 257 \\
& $\mathrm{CO}_{2}(2)$ & 13.5 & 18.5 & 7.5 & 2.9 & 4.0 & 3.3 & 3.3 \\
$+\mathrm{ABA}$ & $\mathrm{a}$ & 127.0 & 43.5 & 8.2 & 24.0 & 28.4 & 11.0 & 8.3 \\
& $\mathrm{~b}$ & 4380 & 1240 & 622 & 1290 & 1840 & 1590 & 1240 \\
& $\mathrm{CO}_{2}(1)$ & 475 & 268 & 311 & 281 & 243 & 449 & 356 \\
& $\mathrm{CO}_{2}(2)$ & 13.8 & 9.3 & 4.1 & 5.2 & 3.7 & 5.3 & 2.4 \\
\hline
\end{tabular}

a: $\mu \mathrm{g}$ of CHL $/ \mathrm{ml}$ b: $\mu \mathrm{g}$ of $\mathrm{NP} / \mathrm{ml}$

$\mathrm{CO}_{2}$ (1): $\mathrm{CO}_{2}$ per $\mathrm{mg}$ of $\mathrm{CHL} / \mathrm{ml} / \mathrm{hr} \quad \mathrm{CO}_{2}{ }^{(2)}: \mathrm{CO}_{2}$ per $\mathrm{mg}$ of $\mathrm{NP} / \mathrm{ml} / \mathrm{hr}$

- Evaluation for 9 experiments

Relative standard error in the determination of chlorophylls and protein nitrogen respectively: $6 \%$ and $0.25 \%$. 
Table $2 \mathrm{CO}_{2}$ incorporated in orgaric compounds expressed in $\mathrm{nM}$ for two parameters (per $\mathrm{mg}$ of $\mathrm{CHL}$ and per $\mathrm{mg}$ of NP) in zones of isolated chloroplasts from carrot tissues (cultivated 110 days on the Murashige and Skoog medium) and pretreated in a phosphate buffer, $\mathrm{pH} 6.1$, with or without $1 \cdot 10^{-5} \mathrm{M} A B A$ for $17 \mathrm{hr}$

\begin{tabular}{llccccccc}
\hline & & \multicolumn{7}{c}{ Concentration of sucrose in \% } \\
\cline { 3 - 9 } No ABA & $\mathrm{a}$ & 73 & 42 & 51 & 57 & 60 & 63 & 66 \\
& $\mathrm{~b}$ & 2000 & 1070 & 2120 & 1520 & 783 & 1570 & 1610 \\
& $\mathrm{CO}_{2}(1)$ & 1070 & 344 & 2480 & 885.0 & 237.2 & 149.0 & 155.6 \\
& $\mathrm{CO}_{2}(2)$ & 42.0 & 19.0 & 52.2 & 22.1 & 7.4 & 5.2 & 4.1 \\
$+\mathrm{ABA}$ & $\mathrm{a}$ & 103.0 & 98.6 & 91.2 & 24.9 & 18.4 & 15.9 & 14.0 \\
& $\mathrm{~b}$ & 1750 & 830 & 2030 & 740 & 740 & 1110 & 900 \\
& $\mathrm{CO}_{2}(1)$ & 602 & 282 & 205 & 332 & 377 & 465 & 415 \\
& $\mathrm{CO}_{2}(2)$ & 35.4 & 33.5 & 9.2 & 11.2 & 9.5 & 6.7 & 6.5 \\
\hline
\end{tabular}

For $a, b, \mathrm{CO}_{2}{ }^{(1)}$ and $\mathrm{CO}_{2}(2)$, see Table 1 .

The chloroplast pattern of ABA-treated tissues is similar to that of old tissues; groups I and III remain. After treatment with ABA, two important populations of chloroplasts appear in the 51 and $57 \%$ sucrose zones, in an identical pattern as for 110 day-old tissues. ABA accelerates explant aging and produces the typical chloroplast pattern of old tissues. With $10^{-4} \mathrm{M}$, "senescence" is set, almost all groups of chloroplasts are touched. Those of group III are destroyed, and the tissues become necrotic.

\section{Gonclusion}

To explain the present data, two complementary hypotheses must be briefly presented. ABA may first have a direct action on chloroplast differentiation-as previously reported (7)-in carrot tissues cultivated in vitro, causing thereby an acceleration of tissue maturation. But ABA could also control the metabolism-as already discussed (12) —of the carrot tissues cultured in vitro, inducing some aging processes which could very well explain a rapid increase in the chloroplast content, usually higher in senescent tissues.

On the other hand, whichever type of treatment is applied to the tissues (pretreatment or continuous application of ABA), it always results in an inhibition of the Ru-DP carboxylase of chloroplasts isolated from the carrot tissues cultivated in vitro and a strong decrease in the ${ }^{14} \mathrm{CO}_{2}$ fixation as well.

We express our thanks to Dr. Rose-Maric Hofer, from our Institute, for her helpful participation in the present work

\section{References}

(1) Arnon, D. I.: Copper enzymes in isolated chloroplasts in Beta vulgaris. Plant Physiol. 24: 1-15 (1949).

( 2 ) Bourdu, R., Y. Mathieu, M. Miginiac-Maslow, R. Remy and A. Moyse: Structure granaire, réduction du NADP et photophosphorylation des chloroplastes isolés de feuilles d'orge. Planta 80: $191-210$ (1968). 
(3) Bruinsma, J.: The quantitative analysis of chlorophylls $a$ and $b$ in plant extracts. Photochem. Photobiol. 2: 241-249 (1963).

(4) Gautheret, R. J.: La culture des tissus végétaux. Masson Ed., Paris, 1959.

(5) Hanson, A. D. and J. Edelman: Photosynthesis by carrot tissue cultures. Planta 102: 11-25 (1972).

(6) Leech, R. M.: The isolation of structurally intact chloroplasts. Biochim. Biophys. Acta 79: 637-639 (1964).

(7) Milborrow, B. V.: The chemistry and physiology of abscisic acid. Ann. Reu. Plant Physiol. 25: 259-307 (1974).

( 8 ) Pilet, P. E. and M. Fragata: Protéines et gradients auxines-oxydasiques dans les racines de carotte cultivées in vitro. Rev. gén. Bot. 70: 572-587 (1963).

(9) Pilet, P. E.: Auxines et polarité morphologique des tissus de Carotte cultivés in vitro. ibid. 70: 572-587 (1963).

(10) Pilet, P. E. and M. Fragata: A propos de l'extraction et de l'absorption du tryptophane dans les racines de Carotte cultivées in vitro. C. R. Acad. Sci. $261: 513-516$ (1965).

(11) Pilet, P. E. and J. Cl. Roland: Effects of abscisic acid on the growth and ultrastructure of tissues cultivated in vitro. Cytobiologie 4: 41-61 (1971).

(12) Pilet, P. E.: ABA effects on growth in relation to auxin, RNA and ultrastructure. In Hormonal Regulation in Plant Growth and Development. Edited by H. Kaldewey and Y. Varder. p. 297-315. Verlag Chemie, Weinheim, 1972.

(13) Roland, J. Cl. and P. E. Pilet: Modifications ultrastructurales des parois de cellules de Ronce sous l'effect de l'acide abscissique. C. R. Acad. Sci. 272: 72-75 (1971).

(14) Shumway, L. K., T. E. Weier and C. R. Stocking: Crystalline structures in Vicia faba chloroplasts. Planta 76: 182-189 (1967).

(15) Spencer, D. and S. G. Wildman: Observations on the structure of grana-containing chloroplasts and a proposed model of chloroplast structure. Aust. J. Biol. Sci. 15: 599-610 (1962).

(16) Spencer, D. and H. Unt: Biochemical and structural correlations in isolated spinach chloroplasts under isotonic and hypotonic conditions. ibid. 18: 197-210 (1965).

(17) Wildman, S. G., K. Chen, J. C. Gray, S. D. Kung, P. Kwanyuen and K. Sakano: Evolution of ferredoxin and fraction I protein in the genus Nicotiana. In Genetics and Biogenesis of Chloroplasts and Mitochondria. Edited by P.S. Perlman, C. W. Birky and T. J. Byers. State Univ. Press, Columbus. Chap. 9, p. 309-329. 1975. 
